\title{
The effect of some salts on head weight and tipburn of lettuce and on fruit production and blossom-end rot of tomatoes*
}

\author{
C. Sonneveld and J. van den Ende \\ Glasshouse Crops Research and Experiment Station, Naaldwijk, the Netherlands
}

\section{Summary}

In an experiment with tomatoes and lettuce grown in containers various salts were added to the irrigation water. Binary salts were added in quantities of $121 / 2$ and $25 \mathrm{mmol}$ and tertiary salts in quantities of $81 / 3$ and $16^{2} / 3 \mathrm{mmol}$ per litre water. The tomato yield was reduced by $16 \%$ at the low salt level and by $28 \%$ at the high salt level. The yield reductions for lettuce were 11 and $26 \%$, respectively. No significant differences were found in tomato yields as a result of the various salts. Sodium bicarbonate gave a greater yield reduction in lettuce than the other salts.

The incidence of tipburn in lettuce was influenced by the different salt treatments. Calcium chloride reduced tipburn but most other salts, in particular sodium bicarbonate, increased the disorder. Some blossom-end rot occurred in tomatoes as a result of the salt applications. Magnesium chloride resulted in more blossomend rot than the other salts.

The soil was analysed at regular intervals by means of the saturation extract. Low calcium and magnesium figures were obtained after the application of sodium bicarbonate. The uptake of nutrients in the different treatments was determined by the analysis of leaf and fruit samples. The application of the different salts was clearly reflected in the chemical composition of the crop.

\section{Introduction}

Almost all crops grown under glass are salt sensitive. High salt concentrations in the soil result in reduced growth and yield. Yellowing, leaf scorch and other physiogenic disorders may also occur, often causing a reduction in the quality of the harvested produce. The main cause of salt damage is usually the osmotic effect. In other words, the damage is mainly the result of reduced availability of soil moisture. However, sometimes the damage on saline soils may be caused to a large extent by the specific effect of one ion or another. In these cases the damage is partly the result of either the uptake of toxic quantities of a certain ion or the inadequate uptake of an essential nutrient element. Extensive research has been carried out at the Naaldwijk Research Station, directed in particular at the osmotic effect of salts on glasshouse crops. Specific ion effects were also found during these

* Publikatie van het Proefstation voor de Groenten- en Fruitteelt onder Glas te Naaldwijk No 203. 
investigations. For example, tipburn in lettuce proved to be closely related to the sodium chloride concentration and less so with the total salt concentration.

To obtain more information about specific ion effects in horticultural crops, an experiment was started in 1971 in which the effects of various salts were compared. The results for lettuce and tomatoes are reported in this publication.

\section{Methods}

\section{Experimental design}

The experimental crops were irrigated with water to which various salts has been added. The salts were divided into two groups. One group consisted of salts with the same anion but different cations. The reverse was true for the other group. A control treatment was included in both groups. The following salts were compared: cation group

$\mathrm{NaCl}$

$\mathrm{KCl}$ anion group

$\mathrm{CaCl}_{2}$ $\mathrm{MgCl}_{2}$ $\mathrm{NaNO}_{3}$
$\mathrm{NaCl}$
$\mathrm{Na}_{2} \mathrm{SO}_{4}$
$\mathrm{NaHCO}_{3}$

The binary salts were added in concentrations of $12 \frac{1}{2}$ and $25 \mathrm{mmol}$ and the tertiary salts in concentrations of $8^{1 / 3}$ and $16^{2} / 3 \mathrm{mmol}$ per litre water. The total ion concentration of the irrigation water was therefore the same in all cases.

The salts were added to tap water which itself contained about $4 \frac{1}{2}$ meq $\mathrm{Na}^{+}$, 6 meq $\mathrm{Ca}^{2+}, 1 \mathrm{meq} \mathrm{Mg}^{2+}, 3 \mathrm{meq} \mathrm{H} \mathrm{CO}_{3}-, 21 / 2 \mathrm{meq} \mathrm{SO}_{4}{ }^{2-}$ and 6 meq Cl- per litre.

A nutrient solution was added in a concentration considered optimal for the development of the crop. Overhead irrigation was used for lettuce and low-level irrigation for tomatoes.

The treatments were in four replicates. An experimental plot consisted of two containers with a surface area of 50 by $50 \mathrm{~cm}$ and a depth of $50 \mathrm{~cm}$. A gravel layer on the bottom of the container provided for drainage of surplus water. The experiment was carried out in an unheated Venlo block. The soil was a light calcareous loam with about $5 \%$ organic matter.

\section{Growing conditions}

The experiment included two tomato and four lettuce crops. Two tomato or four lettuce plants were grown in each container. The tomatoes were planted at the end of April and cleared at the end of September. Three of the lettuce crops were grown in the period January/February to March/April. The fourth lettuce crop was planted at the end of September and harvested mid-November. Water was applied regularly and the soil moisture tension was therefore low, usually 40 to $50 \mathrm{mmHg}$ $(5332$ to $6665 \mathrm{~Pa})$. Higher values were obtained from time to time with tomatoes. The quantity of irrigation water was such that some leaching of salts occurred during the cropping season. Once a year the soil was thoroughly leached with 200 to $300 \mathrm{~mm}$ of water after the main crop had been cleared. For this purpose water was used to which salts had been added according to the salt treatments of the plots. 


\section{Soil testing}

With both tomato crops the soil was sampled and analysed half way through the cropping season. With lettuce the soil was also sampled twice immediately after the crop had been harvested. The soil samples were taken from the upper $25 \mathrm{~cm}$ of the profile. The soil was dried and the main cations, anions, the $\mathrm{pH}$, and the electrical conductivity were determined in the saturation extract. The phosphate content was expressed in $\mathrm{mg} P$ per litre, the other ions in meq per litre and the conductivity in $\mathrm{mmho}\left(=\mathrm{mS}=\mathrm{m} \Omega^{-1}\right)$ per $\mathrm{cm}$ at $25^{\circ} \mathrm{C}$.

\section{Tissue analysis}

Crop samples were collected from one tomato and two lettuce crops. In the case of tomatoes samples of mature fruits and young fully grown leaves were taken three weeks after the start of picking. The lettuce samples consisted of whole heads taken at harvest. The samples were dried and analysed for chloride, sodium and the main nutrient elements.

\section{Results with tomatoes}

\section{Yield}

The results obtained with the two tomato crops were consistent and they have therefore been averaged (Table 1). The salts in the irrigation water have clearly affected yield. However, the differences in yield between the different salts were small. Statistically significant differences could only be demonstrated within the anion group. The application of sodium chloride gave a slightly lower yield and the application of sodium bicarbonate a slightly higher yield than the other salts.

The differences in yield were caused by both differences in the number of harvested fruits and in the average fruit weight.

Table 1. Average yield of two tomato crops in $\mathrm{kg}$ per plant.

\begin{tabular}{|c|c|c|c|c|c|c|c|}
\hline \multirow[t]{2}{*}{ Salts } & \multicolumn{3}{|c|}{ Concentration $^{1}$} & \multirow[t]{2}{*}{ Salts } & \multicolumn{3}{|c|}{ Concentration ${ }^{1}$} \\
\hline & 1 & 2 & average & & 1 & 2 & average \\
\hline $\mathrm{NaCl}$ & 5.49 & 4.52 & 5.00 & $\mathrm{NaNO}_{3}$ & 5.28 & 4.67 & 4.98 \\
\hline $\mathrm{KCl}$ & 5.37 & 4.34 & 4.86 & $\mathrm{NaCl}$ & 4.93 & 4.52 & 4.72 \\
\hline $\mathrm{CaCl}_{2}$ & 5.37 & 4.49 & 4.93 & $\mathrm{Na}_{2} \mathrm{SO}_{4}$ & 5.41 & 4.75 & 5.08 \\
\hline $\mathrm{MgCl}_{2}$ & 5.52 & 4.72 & 5.12 & $\mathrm{NaHCO}_{3}$ & 5.58 & 4.88 & 5.23 \\
\hline Average & 5.44 & 4.52 & 4.98 & Average & 5.32 & 4.70 & 5.01 \\
\hline Control & & & 6.52 & Control & & & 6.31 \\
\hline
\end{tabular}

1 Concentration $1: 12^{1 / 2} \mathrm{mmol} / 1$ water for binary salts, $8^{1 / 3} \mathrm{mmol} / 1$ water for tertiary salts. Concentration 2: $25 \mathrm{mmol} / 1$ water for binary salts, $16^{2} / \mathrm{s} \mathrm{mmol} / 1$ water for tertiary salts. 
Table 2. Tomatoes with blossom-end rot and uneven ripened fruits (\%).

\begin{tabular}{lll}
\hline Treatment & Blossom-end rot & Uneven ripened \\
& & \\
Control & 0.0 & 1.5 \\
Concentration 1* & 0.3 & 0.4 \\
Concentration 2* & 1.4 & 0.3 \\
\hline
\end{tabular}

* See footnote to Table 1.

\section{Blossom-end rot and uneven ripening}

Blossom-end rot and blotchy ripening were not very prevalent. Blotchy ripening occurred mostly in the first year and blossom-end rot in the second year. The percentage affected fruits, averaged for both years, is shown in Table 2. An increase in the salt concentration of the irrigation water encouraged blossom-end rot and discouraged blotchy ripening. The percentage of fruits affected by blossom-end rot was relatively high at the high magnesium chloride concentration $(4.1 \%)$. Otherwise there were no great differences in the appearance of the fruits.

\section{Results with lettuce}

\section{Yield}

The weight of the heads was consistent for the different crops and the averages for the four crops are shown in Table 3. Increased salt concentrations resulted in lower head weights. Generally sodium bicarbonate proved to be more harmful than the other salts, particularly at the high concentration. Significant differences were hardly found between the other salts.

Table 3. Average yield of four lettuce crops (g per head).

\begin{tabular}{|c|c|c|c|c|c|c|c|}
\hline \multirow[t]{2}{*}{ Salts } & \multicolumn{3}{|c|}{ Concentration $^{1}$} & \multirow[t]{2}{*}{ Salts } & \multicolumn{3}{|c|}{ Concentration ${ }^{1}$} \\
\hline & 1 & 2 & average & & 1 & 2 & average \\
\hline $\mathrm{NaCl}$ & 251 & 218 & 234 & $\mathrm{NaNO}_{3}$ & 255 & 222 & 238 \\
\hline $\mathrm{KCl}$ & 258 & 210 & 234 & $\mathrm{NaCl}$ & 249 & 198 & 224 \\
\hline $\mathrm{CaCl}_{2}$ & 244 & 218 & 231 & $\mathrm{Na}_{2} \mathrm{SO}_{4}$ & 252 & 218 & 235 \\
\hline $\mathrm{MgCl}_{2}$ & 248 & 203 & 226 & $\mathrm{NaHCO}_{3}$ & 235 & 170 & 202 \\
\hline Average & 250 & 212 & 231 & Average & 248 & 202 & 225 \\
\hline Control & & & 279 & Control & & & 282 \\
\hline
\end{tabular}

1 See footnote to Table 1. 


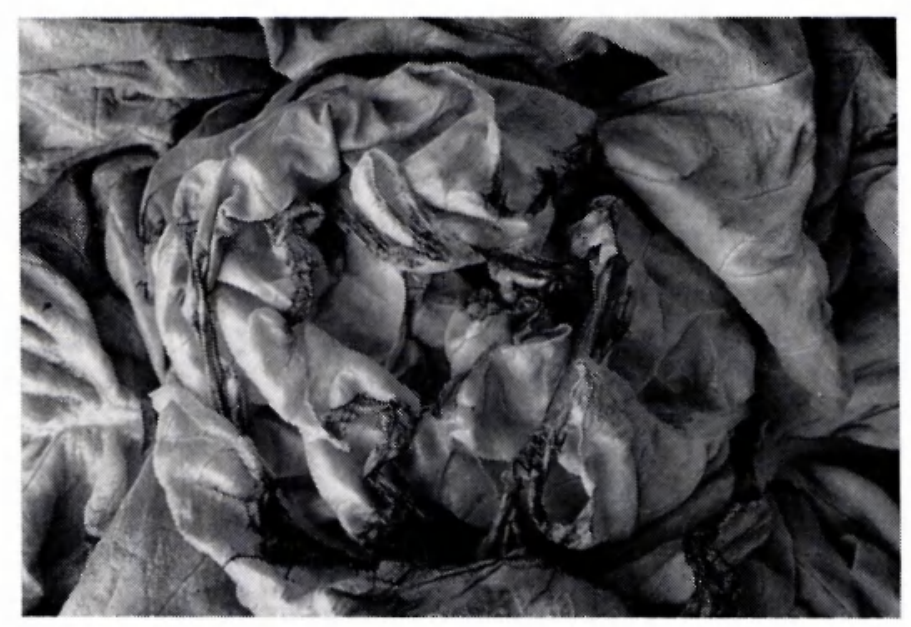

Fig. 1. 'Normal tipburn' of lettuce.

\section{Tipburn}

Tipburn occurred in all four lettuce crops; the symptoms are illustrated in Fig. 1. They have been described as 'normal tipburn' by Termohlen \& van der Hoeven (1965) and Roorda van Eysinga \& Smilde (1971). Average assessments of the degree of tipburn are shown in Table 4. The effects of the various salts on tipburn were consistent in the four lettuce crops. Most of the salts caused an increase in tipburn, particularly sodium bicarbonate. Potassium chloride did not increase tipburn and calcium chloride prevented the disorder almost completely.

The high concentration of sodium bicarbonate caused more severe tipburn than the low concentration. The opposite effect was obtained with potassium chloride. The effects of concentration of the other salts varied with the different crops.

Table 4. Average index figures for tipburn of four lettuce crops. 1-3 light; 4-6 moderate, and 7-10 severe symptoms.

\begin{tabular}{|c|c|c|c|c|c|c|c|}
\hline \multirow[t]{2}{*}{ Salts } & \multicolumn{3}{|c|}{ Concentration $^{1}$} & \multirow[t]{2}{*}{ Salts } & \multicolumn{3}{|c|}{ Concentration ${ }^{1}$} \\
\hline & 1 & 2 & average & & 1 & 2 & average \\
\hline $\mathrm{NaCl}$ & 3.2 & 2.8 & 3.0 & $\mathrm{NaNO}_{3}$ & 3.9 & 3.4 & 3.6 \\
\hline $\mathrm{KCl}$ & 2.3 & 1.4 & 1.8 & $\mathrm{NaCl}$ & 2.8 & 2.6 & 2.7 \\
\hline $\mathrm{CaCl}_{2}$ & 0.4 & 0.2 & 0.3 & $\mathrm{Na}_{2} \mathrm{SO}_{4}$ & 3.8 & 4.2 & 4.0 \\
\hline $\mathrm{MgCl}_{2}$ & 4.6 & 4.8 & 4.7 & $\mathrm{NaHCO}_{3}$ & 4.9 & 7.6 & 6.2 \\
\hline Average & 2.6 & 2.3 & 2.4 & Average & 3.8 & 4.4 & 4.1 \\
\hline Control & & & 1.7 & Control & & & 1.6 \\
\hline
\end{tabular}

${ }^{1}$ See footnote to Table 1.

Neth. J. agric. Sci. 23 (1975) 


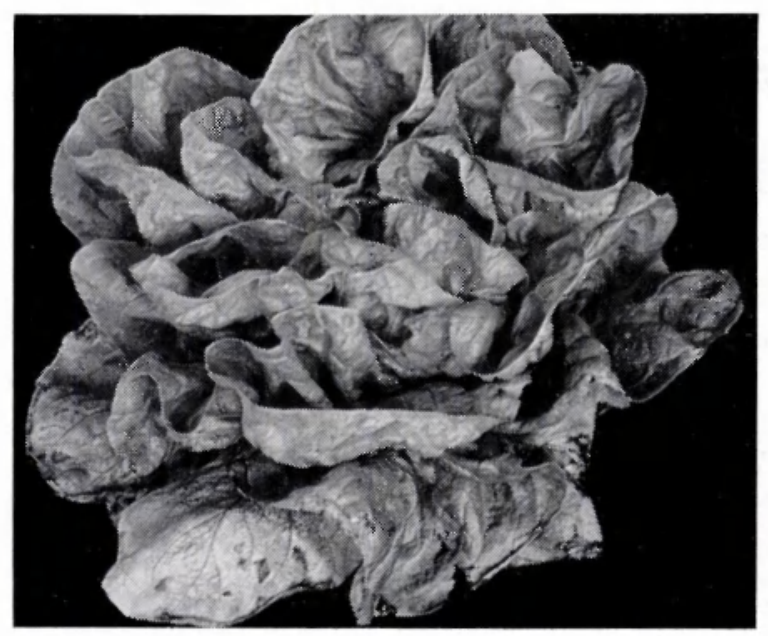

Fig. 2. Yellowing and leaf scorch of the older leaves of lettuce caused by high sodium bicarbonate concentrations.

Sometimes tipburn was more severe at the high concentrations and at other times it was more severe at the low concentration. Apart from causing severe tipburn, the high level of sodium bicarbonate sometimes resulted also in yellowing and leaf scorch of the older leaves (Fig. 2).

Table 5. Analytical data of saturation extracts. The electrical conductivity (E.C.) is given in $\mathrm{mmho} / \mathrm{cm}$ at $25^{\circ} \mathrm{C}$, the phosphate in $\mathrm{mg} \mathrm{P}$ per litre and the other ions in meq per litre.

\begin{tabular}{|c|c|c|c|c|c|c|c|c|c|c|c|c|}
\hline Treatment $^{1}$ & $\mathrm{Na}^{+}$ & $\mathrm{K}^{+}$ & $\mathrm{Ca}^{2+}$ & $\mathrm{Mg}^{2+}$ & $\mathrm{NH}_{1^{+}}{ }^{+}$ & $\mathrm{Cl}$ & $\mathrm{NO}_{3}{ }^{-}$ & $\mathrm{SO}_{4}{ }^{2-}$ & $\mathrm{HCO}_{3}$ & ${ }^{-P}$ & E.C. & $\mathrm{pH}$ \\
\hline Control & 10 & 3.7 & 17.3 & 9.2 & 0.2 & 11.1 & 8.7 & 19.5 & 1.9 & 6.2 & 3.66 & 80 \\
\hline $\mathrm{NaCl} 1$ & 34.2 & 4.3 & 18.3 & 10.0 & 0.2 & 36.4 & 8.7 & 20.9 & 1.9 & 7.7 & 6.00 & 7.2 \\
\hline & 47.7 & 4.1 & 16.5 & 7.7 & 0.2 & 49.5 & 9.0 & 16.7 & 1.9 & 8.6 & 7.02 & 7.3 \\
\hline $\mathrm{KCl} 1$ & 10.6 & 22.2 & 20.9 & 10.6 & 0.2 & 33.6 & 8.8 & 21.2 & 1.7 & 7.7 & 6.22 & 7.3 \\
\hline & 10.2 & 41.7 & 21.0 & 10.2 & 0.2 & 53.0 & 8.8 & 18.1 & 1.9 & 6.9 & 7.94 & 7.1 \\
\hline $\mathrm{CaCl}_{2} 1$ & 11.6 & 4.4 & 48.4 & 13.3 & 0.2 & 46.1 & 8.9 & 21.0 & 1.5 & 3.4 & 6.64 & 7.3 \\
\hline & 10.2 & 4.5 & 65.0 & 11.9 & 0.2 & 64.9 & 9.7 & 15.8 & 1.4 & 2.6 & 7.91 & 7.2 \\
\hline $\mathrm{MgCl}_{2} 1$ & 10.4 & 4.3 & 22.7 & 32.9 & 0.2 & 41.8 & 9.6 & 17.6 & 1.7 & 11.0 & 6.26 & 7.1 \\
\hline 2 & 9.4 & 5.1 & 23.9 & 52.5 & 0.1 & 62.7 & 9.3 & 18.2 & 1.8 & 13.8 & 7.57 & 7.2 \\
\hline Control & 11.3 & 4.0 & 17. & 9.9 & 0.3 & 11 & 6 & 19 & 1.9 & 7.2 & 3.81 & 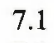 \\
\hline $\mathrm{NaNO}_{3} 1$ & 36. & 4.6 & 17.5 & 9.2 & 0.2 & 17.2 & 29.8 & 18.3 & 2.2 & 7.6 & 6.15 & 7.1 \\
\hline & 54 & 5.3 & 18.2 & 9.4 & 0.2 & 11.5 & 55.7 & 18.8 & 2.2 & 10.3 & 7.40 & 7.3 \\
\hline $\mathrm{NaCl} 1$ & 32.9 & 3.7 & 16.5 & 8.0 & 0.2 & 32.9 & 8.3 & 17.6 & 2.0 & 8.2 & 5.60 & 7.5 \\
\hline 2 & 47.4 & 4.3 & 13.1 & 7.9 & 0.3 & 44.9 & 12.0 & 13.4 & 2.2 & 10.5 & 6.67 & 7.3 \\
\hline $\mathrm{Na}_{2} \mathrm{SO}_{4} 1$ & 41.0 & 4.4 & 19.6 & 10.0 & 0.3 & 10.3 & 7.8 & 51.5 & 2.4 & 9.8 & 5.98 & 7.4 \\
\hline 2 & 658 & 4.9 & 19.2 & 9.8 & 0.3 & 10.1 & 8.8 & 79.2 & 2.7 & 12.5 & 7.56 & 7.5 \\
\hline $\mathrm{NaHCO}_{3} 1$ & 35.2 & 4.1 & 7.7 & 4.8 & 0.3 & 12.8 & 11.0 & 24.2 & 3.9 & 12.5 & 4.78 & 7.7 \\
\hline 2 & 43.5 & 4.0 & 3.9 & 2.8 & 0.4 & 12.2 & 13.0 & 21.5 & 8.62 & 21.9 & 4.96 & 8.1 \\
\hline
\end{tabular}

11 and 2 denote concentrations 1 and 2; see footnote to Table 1. 


\section{Results of soil analyses}

The results of the soil analyses were consistent and the averages are shown in Table 5. Application of the various salts in the cation group is clearly reflected in the results. In the anion group this is also the case with sodium nitrate, sodium chloride and sodium sulphate. However, application of sodium bicarbonate caused only a slight increase in the bicarbonate content of the saturation extract. This salt also reduced the calcium and magnesium contents. Apparently, the major part of the bicarbonate precipitated in the soil as calcium and magnesium carbonate.

The phosphate content was clearly affected by calcium chloride and sodium bicarbonate. In the former case the phosphate content was appreciably lower and in the latter case higher than in the control treatments. This may be explained by the high and low calcium contents in the respective treatments. The conductivity reflected the salt applications very well. However, there was only a relatively small increase in conductivity as a result of sodium bicarbonate applications, especially at the high concentration. This was probably related to the precipitation of calcium and magnesium carbonate.

The $\mathrm{pH}$ showed a relatively sharp increase as a result of the application of bicarbonate. With the other salts there was only a slight increase.

Table 6. Analytical data of tomato leaves. Dry matter is expressed in $\%$ of the fresh material and the elements in $\%$ of the dry matter.

\begin{tabular}{|c|c|c|c|c|c|c|c|c|c|}
\hline Treatment ${ }^{1}$ & $\begin{array}{l}\text { Dry } \\
\text { matter }\end{array}$ & $\mathrm{Na}$ & $\mathbf{K}$ & $\mathrm{Ca}$ & $\mathbf{M g}$ & $\mathbf{P}$ & $\mathrm{Cl}$ & $\mathbf{N}$ & $\mathbf{S}$ \\
\hline Control & 9.3 & 0.60 & 3.67 & 4.74 & 0.83 & 0.26 & 2.60 & 3.98 & 1.25 \\
\hline $\mathrm{NaCl} 1$ & 9.1 & 1.54 & 2.93 & 5.04 & 0.90 & 0.26 & 3.84 & 4.11 & 1.27 \\
\hline 2 & 9.1 & 1.72 & 2.71 & 5.30 & 0.87 & 0.28 & 4.24 & 3.98 & 1.43 \\
\hline $\mathrm{KCl} 1$ & 9.7 & 0.43 & 4.74 & 4.56 & 0.76 & 0.26 & 3.24 & 4.18 & 1.32 \\
\hline 2 & 9.3 & 0.38 & 6.70 & 4.03 & 0.72 & 0.28 & 4.20 & 4.13 & 1.07 \\
\hline $\mathrm{CaCl}_{2} 1$ & 10.2 & 0.27 & 3.52 & 6.00 & 0.64 & 0.22 & 3.88 & 3.57 & 1.38 \\
\hline 2 & 9.9 & 0.28 & 3.71 & 6.10 & 0.72 & 0.22 & 4.08 & 3.95 & 1.05 \\
\hline $\mathrm{MgCl}_{2} 1$ & 9.8 & 0.35 & 3.20 & 4.64 & 1.41 & 0.29 & 3.54 & 3.80 & 1.41 \\
\hline & 10.1 & 0.31 & 2.81 & 4.04 & 2.31 & 0.33 & 3.75 & 3.87 & 1.55 \\
\hline Control & 9.6 & 0.59 & 3.69 & 4.34 & 0.92 & 0.28 & 2.60 & 4.00 & 1.24 \\
\hline $\mathrm{NaNO}_{3} 1$ & 10.1 & 1.11 & 3.47 & 4.72 & 0.70 & 0.30 & 1.95 & 3.97 & 1.47 \\
\hline & 10.5 & 1.78 & 2.63 & 4.84 & 0.78 & 0.29 & 1.11 & 4.38 & 1.39 \\
\hline $\mathrm{NaCl} 1$ & 9.5 & 1.24 & 2.95 & 4.80 & 0.80 & 0.28 & 3.58 & 3.99 & 1.36 \\
\hline 2 & 9.3 & 1.52 & 3.27 & 4.66 & 0.85 & 0.29 & 3.03 & 3.92 & 1.10 \\
\hline $\mathrm{Na}_{2} \mathrm{SO}_{4} 1$ & 9.6 & 1.56 & 3.21 & 4.22 & 0.74 & 0.28 & 2.14 & 4.33 & 1.42 \\
\hline 2 & 9.7 & 2.09 & 3.00 & 4.22 & 0.67 & 0.32 & 1.66 & 4.45 & 1.41 \\
\hline $\mathrm{NaHCO}_{3} 1$ & 10.0 & 1.54 & 2.93 & 4.82 & 0.71 & 0.24 & 2.06 & 3.80 & 1.41 \\
\hline 2 & 9.8 & 1.71 & 2.82 & 3.73 & 0.65 & 0.30 & 1.44 & 4.07 & 1.28 \\
\hline
\end{tabular}

11 and 2 denote concentrations 1 and 2; see footnote to Table 1. 


\section{Results of tissue analyses}

The analytical results obtained from tomato leaves and fruits are shown in Tables 6 and 7. The dry matter content of the fruits was increased by the salt applications, but this was not always the case with the leaves. The application of the various cations was clearly reflected in increased levels in the leaves. The sodium content of the leaves was decreased by the application of cations other than sodium. The same phenomenon occurred now and then in the case of the potassium, calcium and magnesium contents. The effects were less clear in the fruits than in the leaves. In the anion group the calcium content was affected by the application of sodium bicarbonate. The chloride content was increased by the application of chlorides and decreased by the application of other anions.

The results of the analyses of the two lettuce crops were consistent. Table 8 shows the average results. The dry matter content of lettuce increased as a result of salt application. In the cation group the effects were roughly the same as those described for tomatoes. In addition, phosphate uptake was reduced by the application of calcium chloride. In the anion group there was a clear effect of sodium bicarbonate on the calcium content. Application of chlorides and sulphates can be traced very well in the crop analyses.

Table 7. Analytical data of tomato fruits. Dry matter is expressed in $\%$ of the fresh material and the elements in \% of the dry matter.

\begin{tabular}{|c|c|c|c|c|c|c|c|c|c|}
\hline Treatment $^{1}$ & $\begin{array}{l}\text { Dry } \\
\text { matter }\end{array}$ & $\mathrm{Na}$ & $\mathrm{K}$ & $\mathrm{Ca}$ & $\mathrm{Mg}$ & $\mathbf{P}$ & $\overline{\mathrm{Cl}}$ & $\mathbf{N}$ & $S$ \\
\hline Control & 5.0 & 0.10 & 5.56 & 0.17 & 0.18 & 0.53 & 0.76 & 2.71 & 0.21 \\
\hline $\mathrm{NaCl} 1$ & 5.5 & 0.23 & 5.44 & 0.18 & 0.18 & 0.53 & 0.92 & 3.38 & 0.23 \\
\hline & 5.8 & 0.25 & 5.19 & 0.14 & 0.17 & 0.54 & 1.16 & 3.01 & 0.18 \\
\hline $\mathrm{KCl} 1$ & 5.6 & 0.09 & 5.74 & 0.24 & 0.18 & 0.53 & 1.00 & 2.94 & 0.21 \\
\hline & 5.8 & 0.07 & 6.29 & 0.09 & 0.18 & 0.46 & 1.14 & 3.18 & 0.15 \\
\hline $\mathrm{CaCl}_{2} 1$ & 5.3 & 0.08 & 5.01 & 0.20 & 0.16 & 0.46 & 1.29 & 2.97 & 0.21 \\
\hline & 5.6 & 0.07 & 5.13 & 0.30 & 0.17 & 0.42 & 1.31 & 3.25 & 0.17 \\
\hline $\mathrm{MgCl}_{2} 1$ & 5.4 & 0.10 & 5.51 & 0.16 & 0.21 & 0.54 & 1.33 & 3.10 & 0.18 \\
\hline 2 & 5.7 & 0.08 & 5.19 & 0.18 & 0.22 & 0.53 & 1.13 & 2.84 & 0.20 \\
\hline Control & 5.0 & 0.10 & 5.36 & 0.24 & 0.19 & 0.61 & 0.74 & 3.00 & 0.23 \\
\hline $\mathrm{NaNO}_{3} 1$ & 5.6 & 0.18 & 5.23 & 0.23 & 0.19 & 0.57 & 0.69 & 3.01 & 0.22 \\
\hline 2 & 6.2 & 0.34 & 4.70 & 0.21 & 0.18 & 0.53 & 0.54 & 3.00 & 0.19 \\
\hline $\mathrm{NaCl} 1$ & 5.5 & 0.21 & 5.16 & 0.23 & 0.18 & 0.56 & 1.03 & 2.83 & 0.19 \\
\hline 2 & 5.6 & 0.23 & 4.99 & 0.30 & 0.19 & 0.55 & 0.95 & 2.90 & 0.19 \\
\hline $\mathrm{Na}_{2} \mathrm{SO}_{4} 1$ & 5.4 & 0.26 & 4.94 & 0.25 & 0.18 & 0.53 & 0.72 & 3.03 & 0.20 \\
\hline 2 & 6.0 & 0.28 & 4.65 & 0.16 & 0.16 & 0.51 & 0.63 & 2.60 & 0.19 \\
\hline $\mathrm{NaHCO}_{3} 1$ & 5.4 & 0.32 & 5.02 & 0.17 & 0.19 & 0.51 & 0.68 & 3.08 & 0.20 \\
\hline 2 & 5.8 & 0.39 & 4.80 & 0.11 & 0.16 & 0.53 & 0.53 & 2.77 & 0.18 \\
\hline
\end{tabular}

11 and 2 denote concentrations 1 and 2; see footnote to Table 1. 
Table 8. Analytical data of lettuce heads. Dry matter is expressed in $\%$ of the fresh material and the elements in $\%$ of the dry matter.

\begin{tabular}{|c|c|c|c|c|c|c|c|c|c|}
\hline Treatment $^{1}$ & $\begin{array}{l}\text { Dry } \\
\text { matter }\end{array}$ & $\mathrm{Na}$ & $\mathrm{K}$ & $\mathrm{Ca}$ & $\mathrm{Mg}$ & $\mathbf{P}$ & $\mathrm{Cl}$ & $\mathbf{N}$ & $S$ \\
\hline Control & 4.1 & 0.94 & 8.82 & 1.32 & 0.58 & 0.92 & 1.68 & 5.17 & 0.32 \\
\hline $\mathrm{NaCl} 1$ & 4.1 & 2.10 & 7.78 & 1.14 & 0.51 & 1.00 & 2.74 & 5.34 & 0.34 \\
\hline 2 & 4.3 & 2.70 & 7.49 & 1.07 & 0.48 & 1.02 & 3.24 & 5.38 & 0.34 \\
\hline $\mathrm{KCl} 1$ & 4.2 & 0.74 & 10.46 & 1.25 & 0.52 & 1.00 & 2.79 & 5.32 & 0.34 \\
\hline & 4.4 & 0.58 & 10.98 & 1.06 & 0.44 & 0.92 & 3.66 & 5.12 & 0.34 \\
\hline $\mathrm{CaCl}_{2} 1$ & 4.3 & 0.68 & 9.02 & 1.92 & 0.58 & 0.78 & 3.26 & 5.10 & 0.34 \\
\hline 2 & 4.7 & 0.58 & 8.50 & 2.06 & 0.52 & 0.75 & 3.99 & 4.96 & 0.32 \\
\hline $\mathrm{MgCl}_{2} 1$ & 4.4 & 0.72 & 8.58 & 1.36 & 0.96 & 1.00 & 2.91 & 5.18 & 0.34 \\
\hline 2 & 4.7 & 0.62 & 8.18 & 1.10 & 1.26 & 1.02 & 3.86 & 4.96 & 0.34 \\
\hline Control & 4.2 & 0.96 & 8.71 & 1.25 & 0.54 & 0.92 & 1.62 & 5.38 & 0.30 \\
\hline $\mathrm{NaNO}_{3} 1$ & 4.4 & 2.12 & 7.32 & 1.12 & 0.49 & 0.93 & 1.88 & 5.32 & 0.34 \\
\hline 2 & 4.8 & 2.72 & 6.08 & 1.12 & 0.46 & 0.92 & 1.90 & 5.39 & 0.31 \\
\hline $\mathrm{NaCl} 1$ & 4.4 & 2.14 & 7.45 & 1.14 & 0.50 & 0.98 & 2.79 & 5.30 & 0.32 \\
\hline 2 & 4.4 & 2.30 & 7.34 & 1.12 & 0.47 & 1.04 & 2.82 & 5.20 & 0.32 \\
\hline $\mathrm{Na}_{2} \mathrm{SO}_{4} 1$ & 4.4 & 2.24 & 7.54 & 1.02 & 0.44 & 1.05 & 1.49 & 5.46 & 0.40 \\
\hline 2 & 4.5 & 2.74 & 6.75 & 1.04 & 0.42 & 1.00 & 1.76 & 5.40 & 0.54 \\
\hline $\mathrm{NaHCO}_{3} 1$ & 4.2 & 2.58 & 7.32 & 1.00 & 0.48 & 1.00 & 1.74 & 5.28 & 0.33 \\
\hline 2 & 4.7 & 3.05 & 6.00 & 0.75 & 0.39 & 0.97 & 1.56 & 5.54 & 0.36 \\
\hline
\end{tabular}

11 and 2 denote concentrations 1 and 2; see footnote to Table 1.

\section{Discussion}

Yield reduction in tomatoes as a result of the addition of various salts to the irrigation water was on average $16 \%$ at the low salt concentration and $28 \%$ at the high. With lettuce yield reductions were $11 \%$ and $26 \%$, respectively. As far as yield is concerned lettuce is therefore certainly not more salt sensitive than tomatoes. This was also shown in previous research in which the crops were grown in glasshouse borders (Sonneveld \& van den Ende, 1969, 1971).

With tomatoes no significant differences in yield were found between the various salts. Tomatoes appear to have low specific sensitivity to the salts used in the experiment. This was already established for sodium chloride in a previous experiment (Sonneveld \& van den Ende, 1971). Blossom-end rot and blotchy ripening occurred to a limited extent only. The incidence of these disorders was clearly influenced by the salt concentration and hardly by the nature of the salts. An exception was magnesium chloride.

Greater variations were expected in the incidence of blossom-end rot as there were large differences in the calcium levels in the soil. Blossom-end rot is usually associated with calcium deficiency (Geraldson, 1957; Spurr, 1959), especially with calcium deficiency in the fruit (Wiersum, 1966). Hardly any blossom-end rot will occur if the calcium content of the fruit is in excess of about $0.08 \%$ (Wiersum, 
1966; Ward, 1973). The crop analyses showed that the calcium content of the fruits was higher than this in all treatments.

Despite the very low calcium status of the soil in the sodium bicarbonate treatments, the calcium content of the fruits was still sufficiently high. This was probably the result of the relatively low salt concentration of the soil solution in these treatments. According to Wiersum (1965), a low concentration of the soil solution is beneficial for the transport of calcium to the fruit. The more severe incidence of blossom-end rot with the high concentration of magnesium chloride is difficult to explain. The calcium content of the fruits with this treatment was not lower than with the other treatments.

As far as yield is concerned, lettuce appears to have a specific sensitivity to sodium bicarbonate. The yield reduction was much greater if this salt was applied than with any of the other salts. The occurrence of tipburn in lettuce showed wide variations according to the salts applied and there was a clear relationship with the calcium supply to the crop. This relationship has also been found by others (Ashkar \& Ries, 1971; Kruger, 1966; Thibodeau \& Minotti, 1969). The fact that tipburn also occurred with the control treatments proves that the tipburn risk exists even with a slight imbalance in the relationship of the ions. An adequate supply of calcium to the roots is therefore not always sufficient if the transport of calcium to the young leaves is not satisfactory (Thibodeau \& Minotti, 1969). In such cases calcium sprays may be effective for the prevention of tipburn (Kruger, 1966; Thibodeau \& Minotti, 1969). The good effects of calcium chloride in our experiment may be the result of a satisfactory calcium supply via the roots as well as via the leaves, as the crop was given overhead irrigation. However, the severe tipburn obtained with the sodium bicarbonate treatment is an indication that the ion relationship of the soil solution played a major part in the incidence of tipburn. The same conclusion may be drawn from the fairly severe cases of tipburn obtained with the application of other sodium salts and magnesium chloride. It is interesting that the application of potassium chloride did not encourage tipburn.

Several research workers (Ashkar \& Ries, 1971; van der Kloes, 1952) have suggested that tipburn of lettuce is encouraged particularly by large nitrogen dressings. In our experiment there was not much difference between the sodium nitrate treatments and the treatments with other salts. However, tipburn is stimulated more by ammonium than by nitrate (Leh, 1970; Wiebe, 1967). The reason for this is probably a reduced calcium uptake in the presence of ammonium (Barker \& Maynard, 1972; Wilcox et al., 1973).

\section{References}

Ashkar, S. A. \& S. K. Ries, 1971. Lettuce tipburn as related to nutrient imbalance and nitrogen. J. Am. Soc. hort. Sci. 96: 448-452.

Barker, A. V. \& D. N. Maynard, 1972. Cation and nitrate accumulation in pea and cucumber plants as influenced by nitrogen nutrition. J. Am. Soc. hort. Sci. 97: 27-30.

Geraldson, C. M., 1957. Factors affecting calcium nutrition of celery, tomato and pepper. Proc. Soil Sci. Soc. Am. 21: 621-625.

Kloes, L. J. J. van der, 1952. Het randen van sla. Meded. Dir. Tuinb. 15: 125-139. 


\section{EFFECT OF SOME SALTS ON LETTUCE AND TOMATOES}

Kruger, N. S., 1966. Tipburn of lettuce in relation to calcium nutrition. Qd. J. agric. Anim. Sci. 23: $379-385$.

Leh, H. O., 1970. Untersuchungen über die Blattrandbräune bei Kopfsalat unter besonderer Berücksichtigung der Nährstoffaufnahme. NachrBl. Dt. PflSchutzdienst 22: 86-89.

Roorda van Eysinga, J. P. N. L. \& K. W. Smilde, 1971. Nutritional disorders in glasshouse lettuce. Centre for Agricultural Publishing and Documentation, Wageningen.

Sonneveld, C. \& J, van den Ende, 1969. De invloed van zout gietwater bij de slateelt onder glas. Tuinbouwmededelingen 32: 139-148.

Sonneveld, C. \& J. van den Ende, 1971. De invloed van zout gietwater bij de tomatenteelt onder glas. Bedrijfsontwikkeling 2 (11): 43-51.

Spurr, R., 1959. Anatomical aspects of blossom-end rot in tomato with special reference to calcium nutrition. Hilgardia 28: 269-295.

Termohlen, G. P. \& A. P. van der Hoeven, 1965. Tipburn symptoms in lettuce. Acta Hort. 4: 105-109.

Thibodeau, P. O. \& P. L. Minotti, 1969. The influence of calcium on the development of lettuce tipburn. J. Am. Soc. hort. Sci. 94: 372-376.

Ward, G. M., 1973. Causes of blossom-end rot of tomatoes based on tissue analysis. Can. J. Pl. Sci. 53: 169-174.

Wiebe, H. J., 1967. Untersuchungen über den Blattrandbrand bei Kopfsalat. Gartenbauwissenschaft 32: 375-385.

Wiersum, L. K., 1965. Invloed van groei en verdamping der vruchten op het optreden van neusrot bij tomaten. Meded. Dir. Tuinb. 28: 264-267.

Wiersum, L. K., 1966. Calcium content of fruits and storage tissues in relation of the mode of water supply. Acta bot. neerl. 15: 406-418.

Wilcox, G. E., J. E. Hoff and C. M. Jones, 1973. Ammonium reduction of calcium and magnesium content of tomato and sweet corn leaf tissue and influence on incidence of blossomend rot of tomato fruit. J. Am. Soc. hort. Sci. 98: 86-89. 